\title{
BASEMENT FAULT REACTIVATION IN THE ZAKHO- SILOPI REGION, IRAQI KURDISTAN - TURKEY BORDER
}

\author{
JAMAL A. H. DOSKI \\ Dept. of Soil and Water Sciences, College of Agriculture, University of Duhok, Kurdistan Region-Iraq
}

(Received: September 19, 2016; Accepted for publication: December 1, 2017)

\begin{abstract}
The nature and orientation of underlying Late Precambrian basement structures, and their relationships to the seismic distribution and surface linear structures has provided a basis for studying the basement fault reactivation in the Zakho - Silopi region. This border region between Iraqi Kurdistan and Turkey is located in the north-eastern boundary of the Arabian plate and covers some parts of the Zagros fold-thrust belt as well as the high folded and foothill zones of Iraq. The Zakho - Silopi region is characterized by moderatesized earthquakes of shallow-focus that caused mostly by the neotectonic reactivation of Late Precambrian thrust and strike-slip basement faults due to the on-going active continental collision between Arabia and Eurasia. Four potential NE- and NW-trending seismic lineaments were identified, based on the epicentral alignments of major earthquake and the orientation of nodal fault planes, to be the most seismically active basement faults in the Zakho - Silopi region. Any potential for the future damaging earthquakes throughout this region will be more likely associated with the reactivation of the basement faults along these active seismic lineaments. Therefore, a detailed seismic hazard assessment is recommended for the major cities and urban localities. The present-day stress-field orientation inferred from the inversion of fault plane solutions and lineament analysis indicates that the Zakho - Silopi region is undergoing a continuous state of nearly N-S $\left(\mathrm{NO5}^{\circ} \mathrm{E}\right)$ compression. The trend analysis of lineament patterns and seismic lineaments reveals three dominant basement fault trends in the Zakho - Silopi region; roughly N-S, NE-SW, and NW-SE. These basement faults were probably initiated in Late Precambrian as normal faults, and subsequently inverted into thrust faults with a significant strike-slip component, and reactivated continuously from Late Cretaceous to present-day.
\end{abstract}

KEYWORDS: Iraqi Kurdistan, Zagros fold-thrust belt, Reactivation, Seismic lineaments, Basement faults

\section{INTRODUCTION}

A $\mathrm{t}$ least eleven major earthquakes, with magnitudes 4 to 5.5 , occurred in the Zakho - Silopi region from November 25, 1950 to July 13, 2013. The seismicity and basement fault reactivation of this border region between Iraqi Kurdistan and Turkey so far have not received the extensive attention. The Zakho - Silopi region is located in the north-eastern boundary of the Arabian plate, between latitudes $36^{\circ} 57^{\circ} \mathrm{N}-37^{\circ}$ $16^{\circ} \mathrm{N}$ and longitudes $42^{\circ} 20^{\circ} \mathrm{E}-42^{\circ} 46^{\circ} \mathrm{E}$, and covers some parts of the Zagros fold-thrust belt as well as the high folded and foothill zones of Iraq (Fig. 1). The Dohuk region is characterized generally by WNW-trending detachment folds that involve about $8-9 \mathrm{~km}$ of Phanerozoic sedimentary section above the Late Precambrian basement (Doski and McClay, 2011). The exposed stratigraphic section of the Zakho - Silopi region consists of the Pila Spi, Lower Fars, Upper Fars and Lower Bakhtiari formations with Quaternary sediments (Fig. 2). The topography of this region is characterized by anticlinal ridges and synclinal valleys with an elevation ranges from $400 \mathrm{~m}$ to over $1100 \mathrm{~m}$ above sea level (Fig. 3). The objective of this study is to investigate the nature and orientation of underlying Late Precambrian basement structures and their relationships to the seismicity alignments and surface linear structures in order to evaluate the basement fault reactivation in the Zakho - Silopi region. 


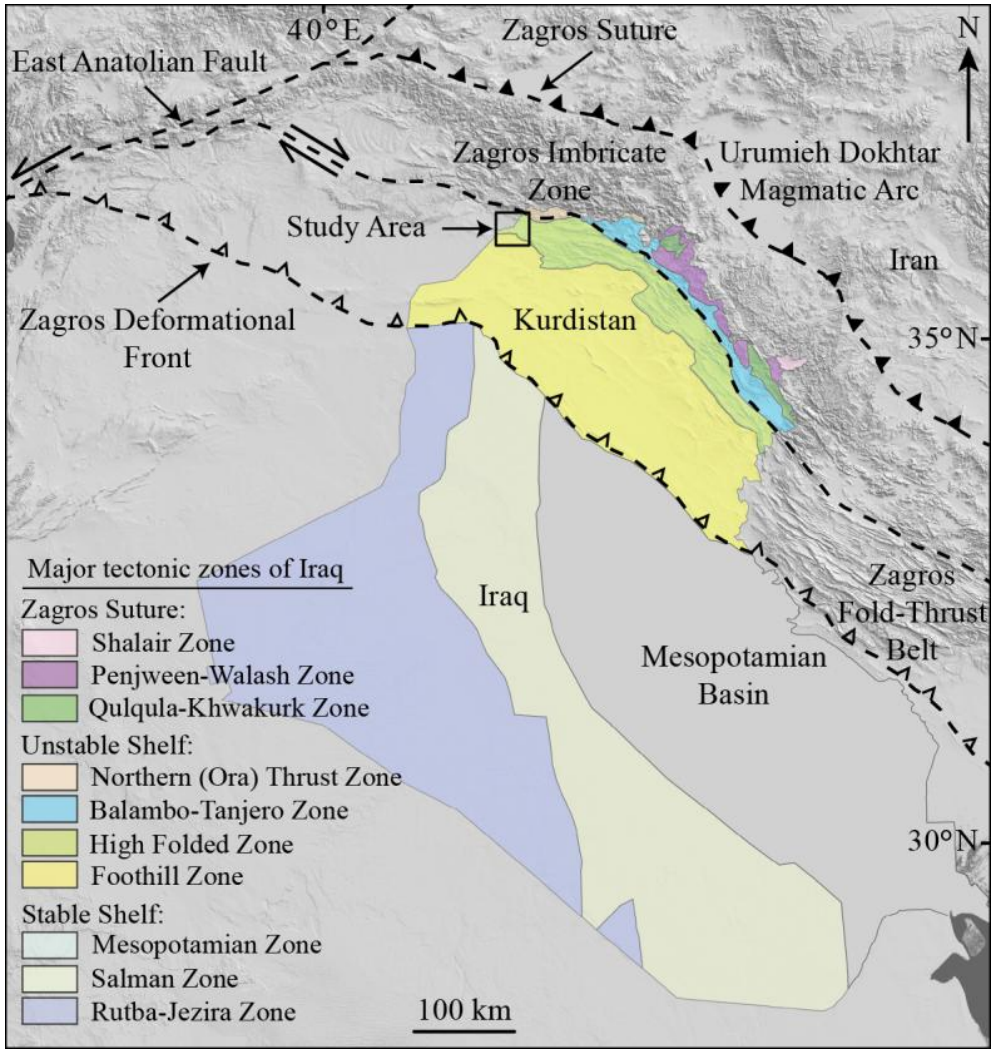

Fig.(1): Tectonic map showing the location of the Zakho - Silopi region (tectonic divisions from Alavi, 2004; Jassim and Goff, 2006).

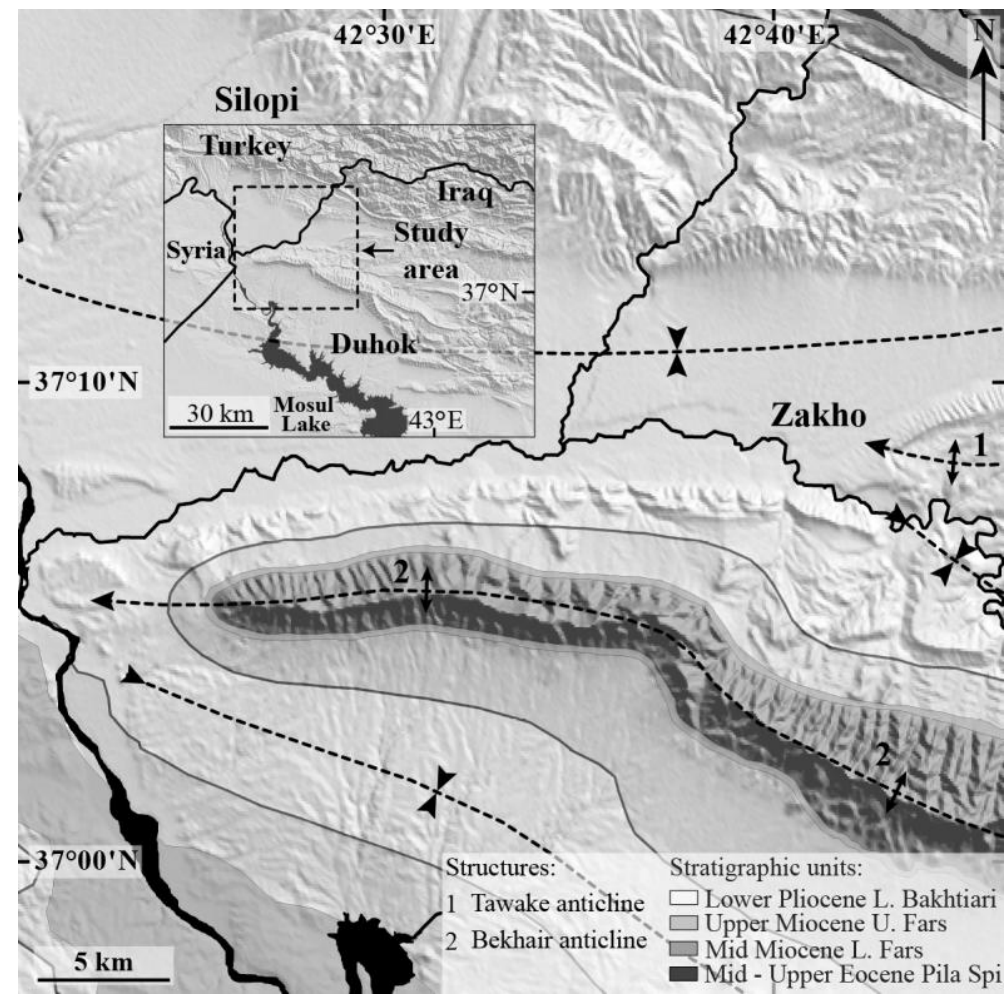

Fig. (2): Geological map of the Zakho - Silopi region (modified from Doski and McClay, 2011). 


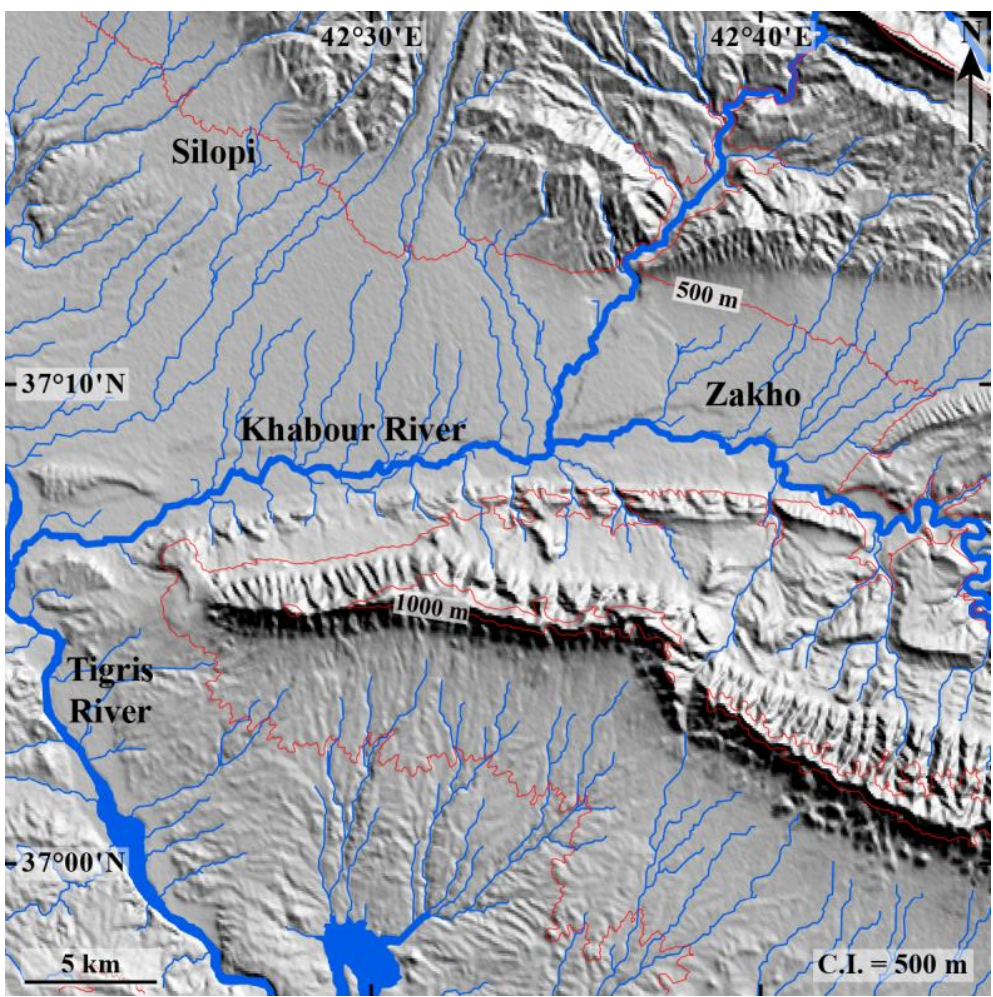

Fig. (3): Drainage network map of the Zakho - Silopi region (derived from ASTER 30 m GDEM)

There have been no specific studies done on the neotectonics of this border region. Four lineament sets, trending NW-SE, NE-SW, N-S and E-W were visually interpreted from the Landsat MSS images by Numan and Bakose (1997) in the western and southern deserts of Iraq, and the orientations of these lineaments were controlled by the basement structures. AlDaghastani and Daood (2005) studied the relationship between seismic activities and tectonic structures in the Nineveh governorate (northern Iraq) using seismic data integrated with the analysis of geological and geomorphological features from Landsat TM images, and concluded that most of the major lineaments are related to the subsurface basement faults. Alridha et al. (2012) studied the seismicity and seismotectonics of the Altunkopri dam (northern Iraq), and the results show a good match between earthquake epicentres and the three predominant sets of lineaments (NESW, NW-SE and E-W), as well as concluded that surface lineaments are directly related to the subsurface basement faults that re-activated due to the continued northerly and north-easterly movements of the Arabian plate.
Four major lineament sets, trending N-S, NESW, NW-SE and E-W, were automatically extracted from Landsat-7 images by Thannoun (2013) in north-west of Mosul (northern Iraq), and interpreted that these four linear sets represent subsurface fracture zones that reactivated under the N-S compression, as well as field data indicates that the orientations of NE- and NWtrending sets coincide with shear fracture trends, whereas the $\mathrm{N}$ - and E-trending sets represent extension fractures in this region. Abdulnaby et al. (2014a and 2014b) studied the seismotectonic activity in northern Iraq and surrounding regions, and calculated the present-day stress patterns using formal inversion of fault plane solutions. The results show that the area is characterized by the dominance of strike-slip and thrust faulting regimes, with fault planes mostly trending in the N-S, NE-SW and E-W directions. Finally, active W-striking thrust and NW-trending strike-slip faults were documented in the Shaikhan area (Kurdistan) by Doski and Mohammad (2016).

\section{Tectonic setting and seismicity}

The Zagros orogen is one of the biggest regions of convergent deformation on Earth (Allen et al., 2004). It is a doubly-vergent asymmetric 
orogenic belt that resulted from the closure of the Neo-Tethys oceanic realm (Alavi, 1994). It was subdivided into three major tectonic units (Fig. 1): the Uremiah-Dokhtar magmatic assemblage, the Zagros imbricate zone and the Zagros fold-thrust belt (Alavi, 2004). The Zagros fold-thrust belt is characterized mainly by asymmetrical, overturned, doubly plunging, NW-trending anticlines, with largely NE-dipping, SW-verging thrusts (Alavi, 2007). The structure of Kurdistan is developed during the formation of the Zagros belt by the continental collision of Arabia with Eurasia followed the final Eocene closure of the NeoTethys Ocean (Numan, 1997; Sharland et al. 2001; Doski and McClay, 2011).

The Zagros belt in Iraq was divided into 3 main tectonic zones (Fig. 2): stable shelf, unstable shelf and suture zone (Jassim and Goff 2006). The unstable shelf of Iraq is characterized mainly by E-W "Taurus" and NW-SE "Zagros" trending fold structures, with an increase in folding intensity toward the north or northeast. The high folded zone has an elevated basement topography $(\sim 8$ $\mathrm{km})$, and characterised by harmonic fold structures with Mesozoic sequences in their cores, and Cenozoic formations on their flanks (Jassim and Buday, 2006b). The foothill zone has the deepest Late Precambrian basement in Iraq $(\sim 13 \mathrm{~km})$ with very thick Neogene - Quaternary sediments $(\sim 3$ $\mathrm{km}$ thick), and characterised by anticlines with cores of Palaeogene or Cretaceous sequences and synclines filled with Neogene - Quaternary sediments (Jassim and Buday, 2006b).

The Arabian basement was formed by terrane accretion along the continental margins in Late Precambrian (Sharland et al., 2001; Jassim, 2006). The basement depth ranges from zero on the Arabian shield to nearly $15 \mathrm{~km}$ in the Mesopotamian basin (Seber et al., 2000). The Triassic-Jurassic rifting and extensional tectonic regime was started at the opening of the NeoTethys Ocean and with the separation of the Iranian and Turkish plates from the Arabian plate, followed by the Cretaceous compressive tectonic regime due to the north and north-eastward subduction of the Neo-Tethyan oceanic crust beneath the Turkish and Iranian plates, leading to the reactivation of both strike-slip (wrench tectonic regimes) and dip-slip reverse (inversion) movements along the pre-existing listric normal faults in the basement, and continued until the final closure of the Neo-Tethys Ocean and the continental collision of the Arabian passive margin with the active margins of the Turkish and Iranian plates from the Late Eocene onwards (Numan, 1997, 2000 and 2001). The strongest orogenic movements and the most effective folding and thrusting in the border folds of Turkey occurred during the Late Miocene time (Ketin, 1966), and still active throughout the eastern Turkey (Okay, 2008).

The Zagros is a seismically active orogen (Jackson et al., 1981; Hessami, 2002). The majority of earthquake events found near the detachment surface between the Late Precambrian basement and Phanerozoic sedimentary rocks, at a depth range $(5-15 \mathrm{~km})$, with thrust and strike-slip faulting focal mechanisms (Mostafazadeh et al., 2000). Most of the earthquakes in the Zagros belt are caused by the reactivation of basement faults (Jackson et al. 1981). Iraq is characterized by moderate- to strong-magnitude earthquakes with relatively shallow focal depths, and most of the fault plane solutions show thrust and strike-slip faulting regimes (Alsinawi and Issa, 1986; Fahmi et al., 1986; Jasim, 2013). However, the seismicity and tectonic setting of the Kurdistan region reflects the present-day reactivation of steeply dipping basement faults (Alsinawi and Issa, 1986; Alsinawi, 2002; Doski and Mohammad, 2016).

\section{MATERIALS AND METHODS \\ Datasets}

There are some random and systematic uncertainties associated with determining the exact epicentre location, depth and magnitude of earthquakes, such as the arrival time picks (Bondár et al., 2004; Dawson and Tregoning, 2007; Husen and Hardebeck, 2010; Bernardi et al., 2014; Gomez-Capera et al., 2015). Therefore; it's really important to use the best earthquake catalogues based on the tectonic setting of the research area. The earthquake data used for this study were obtained from the Turkish AFADDDA catalogue, the Turkish BOUN KOERI Regional Earthquake (BKRE) - Tsunami Monitoring Center (TMC), the European Mediterranean Seismological Centre (EMSC), and the Iranian International Institute of Earthquake Engineering and Seismology (IIEES) as listed in Table 
DOI: https://doi.org/10.26682/avuod.2017.20.1.3

Table (1): List of earthquakes with magnitudes greater than 3.0 in the Zakho - Silopi region.

\begin{tabular}{|c|c|c|c|c|c|c|c|}
\hline Date & Time (UTC) & Latitude & Longitude & Depth $(\mathrm{Km})$ & Magnitude & Magnitude type & Date source \\
\hline 1950.11 .25 & $17: 18: 55$ & 37.07 & 42.48 & 33 & 4.9 & $\mathrm{Mw}$ & BKRE-TMC \\
\hline 1982.01.01 & $19: 30: 24$ & 37.24 & 42.61 & 10 & 4.8 & $\mathrm{Mb}$ & BKRE-TMC \\
\hline 1991.01 .30 & $19: 42: 54$ & 37.11 & 42.65 & 28 & 4.7 & $\mathrm{Mb}$ & BKRE-TMC \\
\hline 1991.02 .02 & $6: 54: 43$ & 37.2 & 42.56 & 26 & 4.7 & $\mathrm{Mb}$ & BKRE-TMC \\
\hline 1991.02 .02 & 9:09:01 & 37.17 & 42.59 & 21 & 4.9 & $\mathrm{Mb}$ & BKRE-TMC \\
\hline 1997.04 .20 & $21: 17: 31$ & 37.011 & 42.646 & 33 & 4.3 & Md & IIEES \\
\hline 2000.10 .24 & $10: 52: 52$ & 37.11 & 42.43 & 10 & 3.9 & Md & BKRE-TMC \\
\hline 2004.02 .01 & $22: 11: 54$ & 37.017 & 42.406 & 10 & 3.7 & Md & IIEES \\
\hline 2004.05 .10 & $20: 51: 46$ & 37.11 & 42.56 & 15 & 3.3 & $\mathrm{Md}$ & BKRE-TMC \\
\hline 2006.02 .02 & $5: 12: 33$ & 37.0117 & 42.5045 & 32.3 & 3.8 & Md & BKRE-TMC \\
\hline 2006.03 .31 & $6: 55: 54$ & 37.2663 & 42.671 & 8.3 & 3.4 & Md & BKRE-TMC \\
\hline 2007.01 .16 & $0: 59: 35$ & 37.22 & 42.39 & 5 & 3.3 & Md & EMSC \\
\hline 2007.05 .08 & $18: 40: 17$ & 37.2665 & 42.3928 & 5 & 3.5 & $\mathrm{Md}$ & BKRE-TMC \\
\hline 2007.07 .26 & $12: 11: 00$ & 37.2365 & 42.7577 & 7.16 & 3.4 & Md & AFAD-DDA \\
\hline 2007.09 .22 & $8: 12: 34$ & 37.15 & 42.61 & 14 & 3.9 & Ml & IIEES \\
\hline 2008.01.19 & $4: 46: 42$ & 37.2 & 42.75 & 7 & 3.4 & Ml & EMSC \\
\hline 2010.01 .04 & $7: 22: 35$ & 37.2655 & 42.7342 & 5.8 & 3.3 & Md & BKRE-TMC \\
\hline 2010.05 .06 & $1: 18: 00$ & 37.188 & 42.7183 & 13.64 & 3.1 & Md & AFAD-DDA \\
\hline 2011.05 .29 & $2: 02: 29$ & 37.2168 & 42.5602 & 11.25 & 4.6 & Ml & AFAD-DDA \\
\hline 2011.06 .27 & $17: 28: 56$ & 37.1393 & 42.4888 & 4.9 & 3.5 & $\mathrm{Md}$ & BKRE-TMC \\
\hline 2011.07 .01 & $0: 47: 00$ & 37.1898 & 42.4522 & 7.02 & 3.2 & Md & AFAD-DDA \\
\hline 2011.11.08 & $21: 46: 09$ & 37.2803 & 42.4262 & 7.9 & 3.1 & $\mathrm{Md}$ & BKRE-TMC \\
\hline 2011.12 .04 & $21: 56: 33$ & 37.1355 & 42.3622 & 7.2 & 3.2 & $\mathrm{Md}$ & BKRE-TMC \\
\hline 2012.05 .13 & $15: 34: 00$ & 37.257 & 42.7402 & 7 & 3.2 & Ml & AFAD-DDA \\
\hline 2012.06.09 & $15: 16: 00$ & 37.2613 & 42.6638 & 5.28 & 3.2 & Ml & AFAD-DDA \\
\hline 2012.06 .14 & $6: 25: 00$ & 37.2422 & 42.5342 & 10.52 & 3.7 & $\mathrm{Ml}$ & AFAD-DDA \\
\hline 2012.06 .14 & $6: 38: 50$ & 37.2795 & 42.4408 & 6.2 & 3.1 & Ml & BKRE-TMC \\
\hline 2012.06 .14 & $8: 50: 01$ & 37.2242 & 42.4355 & 11.06 & 4 & Ml & AFAD-DDA \\
\hline 2012.06 .14 & $8: 52: 51$ & 37.1572 & 42.4437 & 11.68 & 5.5 & Ml & AFAD-DDA \\
\hline 2012.06 .14 & $11: 36: 33$ & 37.2703 & 42.3865 & 5 & 3.2 & Ml & BKRE-TMC \\
\hline 2012.06 .14 & $17: 17: 00$ & 37.2733 & 42.5633 & 13.2 & 3.4 & Ml & AFAD-DDA \\
\hline 2012.06 .14 & $22: 37: 22$ & 37.2797 & 42.401 & 5 & 3.5 & Ml & BKRE-TMC \\
\hline 2012.06 .15 & 0:20:00 & 37.231 & 42.5283 & 16.94 & 3.3 & Ml & AFAD-DDA \\
\hline 2012.06 .16 & $2: 10: 07$ & 37.25 & 42.417 & 5 & 3.9 & Ml & BKRE-TMC \\
\hline 2012.06 .16 & $2: 44: 00$ & 37.2473 & 42.452 & 7.03 & 3.3 & $\mathrm{Ml}$ & AFAD-DDA \\
\hline 2012.06 .16 & $2: 48: 14$ & 37.2097 & 42.4585 & 8.69 & 4.2 & Ml & AFAD-DDA \\
\hline 2012.06 .16 & $3: 12: 00$ & 37.2475 & 42.4725 & 8.8 & 3.7 & Ml & AFAD-DDA \\
\hline 2012.06 .16 & $3: 22: 00$ & 37.238 & 42.46 & 5.06 & 3.8 & Ml & AFAD-DDA \\
\hline 2012.06 .16 & $3: 50: 00$ & 37.1648 & 42.4675 & 6.55 & 3.2 & Ml & AFAD-DDA \\
\hline 2012.06 .19 & $16: 13: 00$ & 37.2583 & 42.5268 & 13.48 & 3.2 & Ml & AFAD-DDA \\
\hline 2012.06 .21 & $22: 09: 30$ & 37.2852 & 42.363 & 5 & 3.2 & Ml & BKRE-TMC \\
\hline 2012.06 .22 & $23: 43: 00$ & 37.2487 & 42.5838 & 6.49 & 3.5 & Ml & AFAD-DDA \\
\hline 2012.07 .08 & $7: 18: 22$ & 37.2375 & 42.4412 & 8.5 & 3.1 & Ml & BKRE-TMC \\
\hline 2012.07 .26 & $19: 27: 00$ & 37.2522 & 42.5145 & 5.21 & 3.2 & $\mathrm{Ml}$ & AFAD-DDA \\
\hline 2012.11 .20 & $7: 19: 23$ & 37.2863 & 42.61 & 10.3 & 3.6 & Ml & BKRE-TMC \\
\hline 2013.06 .04 & $23: 43: 00$ & 37.2028 & 42.4867 & 6.81 & 3.2 & Ml & AFAD-DDA \\
\hline 2013.07.08 & $22: 55: 04$ & 37.0835 & 42.4707 & 16.5 & 3.3 & Ml & BKRE-TMC \\
\hline 2013.07 .10 & $9: 44: 00$ & 37.1438 & 42.4322 & 7.07 & 3.4 & $\mathrm{Ml}$ & AFAD-DDA \\
\hline 2013.07 .10 & $12: 25: 34$ & 37.1055 & 42.4203 & 5 & 3.4 & Ml & BKRE-TMC \\
\hline 2013.07 .13 & $17: 31: 48$ & 37.0747 & 42.415 & 8.8 & 4.4 & Mw & BKRE-TMC \\
\hline 2013.07 .13 & $18: 02: 35$ & 37.2063 & 42.4617 & 7.8 & 3.7 & Ml & BKRE-TMC \\
\hline 2013.07 .13 & $18: 39: 00$ & 37.1287 & 42.4308 & 9.89 & 3.3 & Ml & AFAD-DDA \\
\hline 2013.07 .13 & $19: 19: 00$ & 37.155 & 42.4293 & 12.73 & 3.2 & Ml & AFAD-DDA \\
\hline 2013.09 .25 & $11: 49: 00$ & 37.2555 & 42.5268 & 6.89 & 3.2 & Ml & AFAD-DDA \\
\hline 2014.07 .18 & $16: 24: 00$ & 37.1033 & 42.4346 & 6.68 & 3.2 & Ml & AFAD-DDA \\
\hline 2015.01.11 & $1: 11: 35$ & 37.2372 & 42.4783 & 5.3 & 3.8 & Ml & BKRE-TMC \\
\hline
\end{tabular}


In the last 65 years, nearly 11 earthquakes of M4.0 to 5.5, and about 68 earthquakes of M3.0 to 4.0 have struck the Zakho - Silopi region (Table 1). In general, all earthquakes are shallow (depth $\leq 33 \mathrm{~km}$ ) and of moderate magnitude (magnitude $\leq 5.5$ ) (Fig. 4 and Table 1). Historically, there have been no earthquakes in this region (Ambraseys et al. 1994). The AFAD-DDA catalogue provides fault plane solutions for the 4 biggest events in the Zakho - Silopi region, with magnitudes of $4.0-5.5$, and focal depths at $8.69-$ $11.68 \mathrm{~km}$ (Fig. 5). These focal mechanisms were created by the FOCMEC program using the Pwave first motion data (Snoke et al., 1984). The FOCMEC program provides more realistic solutions even if there is a poor data or limited number of stations (Sasaki and Kaieda, 2002; Snoke 2003; Oros, 2013). The QuickBird images with $0.6 \mathrm{~m}$ resolution, dated 22 June 2005 , were used for mapping of lineament patterns in the Zakho - Silopi region using the ArcGIS software. This data were provided by the Kurdistan Region Statistics Office (KRSO).

\section{Stress tensor inversion analysis}

Focal mechanisms are the best kinematic indicators for the active subsurface faults (Zoback, 2007; Yang et al., 2012). The moment tensor inversion was applied to estimate the directions of recent principal stresses from focal mechanisms of major earthquakes in the Zakho - Silopi region using the rotational optimization method of Delvaux and Sperner (2003) (Win-Tensor program, version 5.8.4). The state of stress is defined by the directions of the main stresses $(\sigma 1$, $\sigma 2$, and $\sigma 3$ ), the horizontal stresses and the stress ratio $(\mathrm{R}=(\sigma 2-\sigma 3) /(\sigma 1-\sigma 3))$.

\section{Lineament analysis}

The analysis of lineament patterns has important implications for seismological and neotectonic studies (Stefouli et al., 1996; La Pointe et al., 1999). Lineaments can be defined as natural linear to curvilinear features that extend for 1 mile or more (Lattman, 1958). Lineaments on satellite images may reflect a number of 2dimensional features, such as fault traces, fracture zones, foliations, lithological boundaries and drainage systems, with little or no information on feature types, their dips or depths (Sander, 2007; Holland, 2012). Lineaments probably represent the surface expression of subsurface structures (Singha and Gupta 2010). The methodology of interpretation involves the identification and mapping of lineaments, based on the field experiences, from QuickBird images using the ArcMap.

\section{Stress inversion}

\section{RESULTS}

The identification of fault and auxiliary planes in the 4 earthquake focal mechanism solutions is mainly dependent on the tectonic setting of the Zakho - Silopi region (Fig. 5). Figure 6 and Table 2 show the directions of the principal stresses, the horizontal stresses and the stress ratio were inverted from the fault plane solutions of largest earthquakes using the rotational optimization method. The moment tensor solutions (no. 2 and 3) show thrust faults with two nodal planes, dipping towards north-east and south-west (Fig. 5). In this case, earthquakes can be confidently related to the NE-dipping planes, as this is consistent with under-thrusting of Arabia beneath the Eurasian plate (Allen et al. 2013). The focal mechanisms (no. 1 and 4) correspond to strike slip faults, with orthogonal nodal planes that oriented NE-SW and NW-SE (Fig. 5). The steeply dipping planes with NW-SE strikes are considered as the probable dextral strike-slip fault planes. These NW-striking dextral strike-slip fault planes are parallel to the Main Recent Fault that trending NW-SE and forming the NE border of the Arabian plate, as well as it accommodates the right-lateral strike-slip motion of the N-S Arabia-Eurasia convergence (Talebian and Jackson, 2002; Authemayou et al. 2009).

The present-day orientation of stress calculated from the inversion of fault plane solutions (no. 1 and 4) show dextral strike-slip faulting regime, with $\sigma 1$ plunging $\left(06^{\circ}\right.$ towards $\left.012^{\circ}\right)$ and $\left(16^{\circ}\right.$ towards $341^{\circ}$ ) respectively, whereas the $\sigma 3$ trending $03^{\circ} / 282^{\circ}$ and $07^{\circ} / 073^{\circ}$ respectively (Fig. 6 and Table 2). The value of the stress ratio $(\mathrm{R}=$ 0.75) suggests that the magnitude of the intermediate principle stress $(\sigma 2)$ is close to the minimum stress ( $\sigma 3)$ (Presti et al., 2013). On the other hand, the state of stress orientation derived from the mechanism solutions (no. 2 and 3) show compressional deformation (thrust faulting regime), with $\sigma 1$ trending $11^{\circ} / 217^{\circ}$ and $00^{\circ} / 232^{\circ}$ respectively, while the $\sigma 3$ plunging ( $79^{\circ}$ towards $\left.040^{\circ}\right)$ and $\left(89^{\circ}\right.$ towards $\left.332^{\circ}\right)$ respectively (Fig. 6 and Table 2). The stress ratio $(\mathrm{R}=0.5)$ indicates unequal magnitudes of the main stresses (Witthuhn-Rolf, 


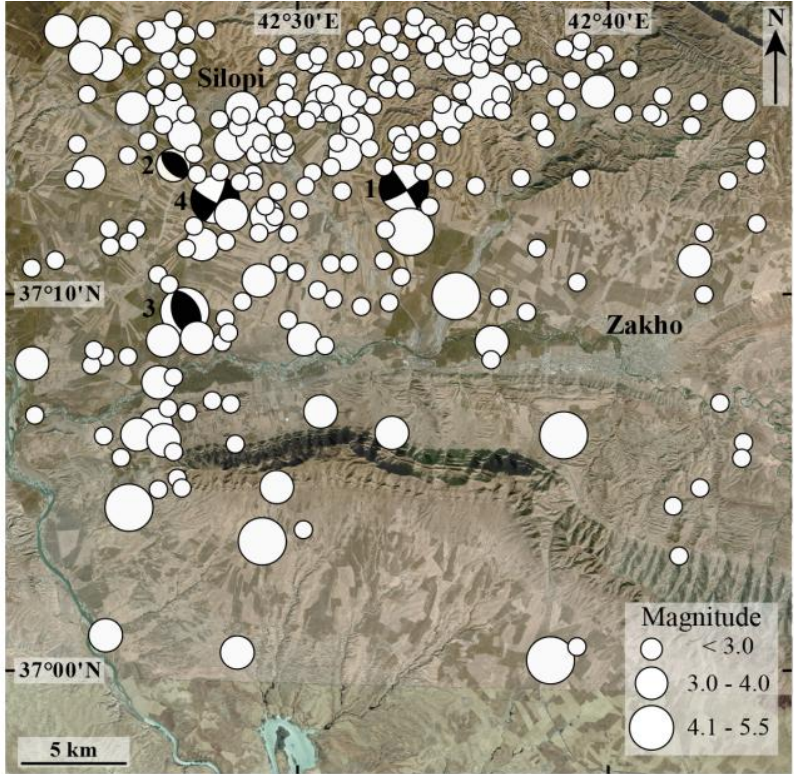

Distance
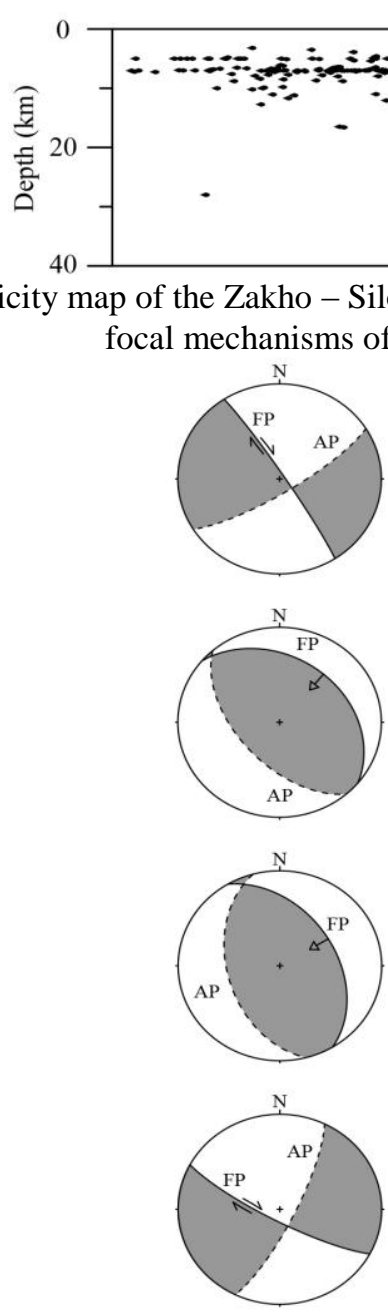
Focal mechanism no. 1

Date: 2011.05.29; Time (UTC): 02:02:29

Latitude: $37.2168^{\circ} \mathrm{N}$; Longitude: $42.5602^{\circ} \mathrm{E}$

Depth $(\mathrm{Km}):$ 11.25; Magnitude: $\mathrm{Ml}=4.6$

Faulting regime: Dextral strike -slip faul

Fault plane: Strike $=327^{\circ}$, Dip $=86^{\circ}$, Rake $($ slip $)=168^{\circ}$ Auxiliary plane: Strike $=058^{\circ} ;$ Dip $=78^{\circ} ;$ Rake (slip) $=4^{\circ}$

Focal mechanism no. 2

Date: 2012.06.14; Time (UTC): 08:50:01

Latitude: $37.2242^{\circ} \mathrm{N}$; Longitude: $42.4355^{\circ} \mathrm{E}$

Depth $(\mathrm{Km}): 11.06$; Magnitude: $\mathrm{Ml}=4.0$

Faulting regime: Thrust

Fault plane: Strike $=310^{\circ} ;$ Dip $=34^{\circ} ;$ Rake (slip) $=82^{\circ}$

Auxiliary plane: Strike $=139^{\circ} ;$ Dip $=56^{\circ} ;$ Rake $($ slip $)=95^{\circ}$

Focal mechanism no. 3

Date: 2012.06.14, Time (UTC): 08:52:51

Latitude: $37.1572^{\circ} \mathrm{N}$; Longitude: $42.4437^{\circ} \mathrm{E}$

Depth $(\mathrm{Km}):$ 11.68; Magnitude: $\mathrm{Ml}=5.5$

Faulting regime: Thrus

Fault plane: Strike $=329^{\circ} ;$ Dip $=44^{\circ} ;$ Rake (slip $)=79^{\circ}$

Auxiliary plane: Strike $=165^{\circ} ;$ Dip $=47^{\circ} ;$ Rake $($ slip $)=101^{\circ}$

Focal mechanism no. 4

Date: 2012.06.16; Time (UTC): 02:48:14

Latitude: $37.2097^{\circ} \mathrm{N}$; Longitude: $42.4585^{\circ} \mathrm{E}$

Depth $(\mathrm{Km}): 8.69$; Magnitude: $\mathrm{Ml}=4.2$

Faulting regime: Dextral strike -slip fault

Fault plane: Strike $=118^{\circ} ;$ Dip $=80^{\circ} ;$ Rake $($ slip $)=-168^{\circ}$

Auxiliary plane: Strike $=026^{\circ} ;$ Dip $=78^{\circ} ;$ Rake (slip) $=-10^{\circ}$

Fig.(5): Focal mechanisms of largest earthquakes in the Zakho - Silopi region (from the Turkish AFAD-DDA catalogue). 


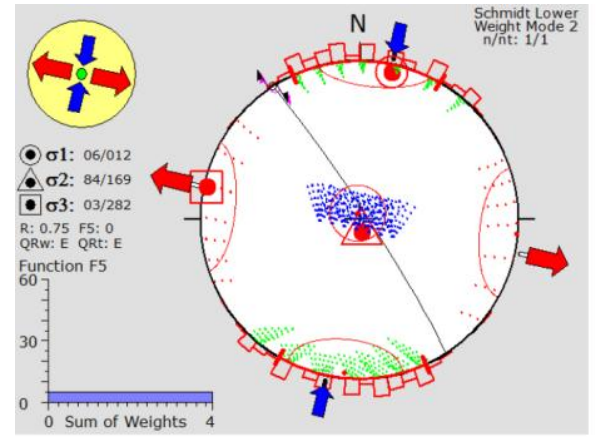

a) Focal mechanism no. 1

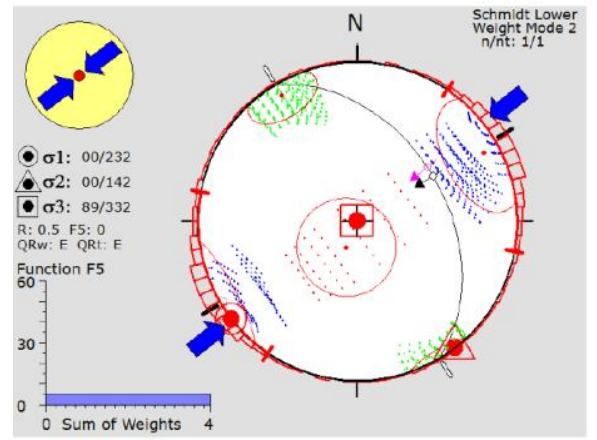

c) Focal mechanism no. 3

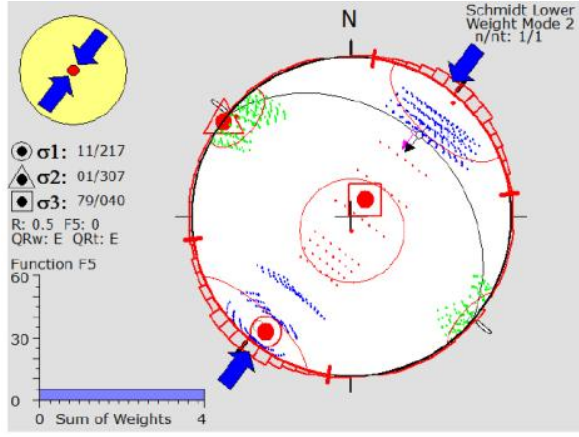

b) Focal mechanism no. 2

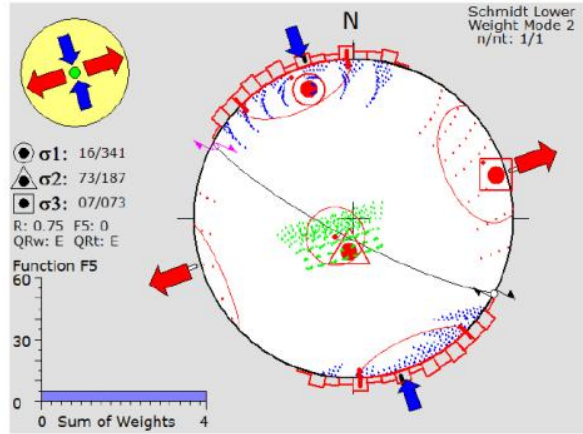

d) Focal mechanism no. 4

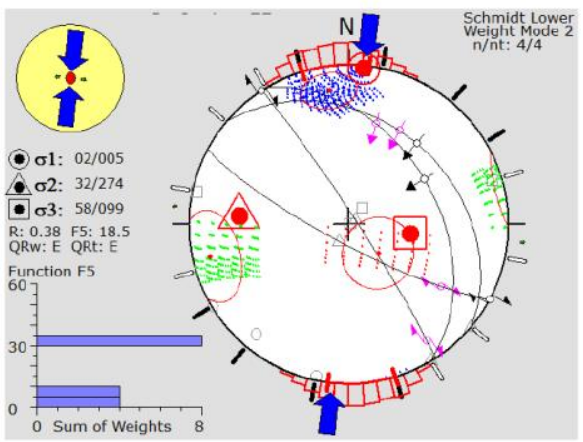

e) Average orientation

Fig.(6): Formal stress inversion of strongest earthquakes in the Zakho - Silopi region by the rotational optimization method (Win-Tensor program).

Table (2): Stress tensor inversion results of the rotational optimization method for the earthquake focal mechanisms in the Zakho - Silopi region.

\begin{tabular}{|c|c|c|c|c|c|c|c|}
\hline \multirow[b]{2}{*}{ Focal mechanism number } & \multicolumn{3}{|c|}{ Moment stress axes } & \multicolumn{4}{|c|}{ Map parameters } \\
\hline & $\sigma 1$ & $\sigma 2$ & $\sigma 3$ & $\begin{array}{l}\text { Maximum } \\
\text { horizontal } \\
\text { stress axis } \\
\text { (SH) }\end{array}$ & $\begin{array}{l}\text { Minimum } \\
\text { horizontal } \\
\text { stress axis } \\
\quad(\mathrm{Sh})\end{array}$ & $\begin{array}{l}\text { Stress } \\
\text { ratio } \\
(\mathrm{R})\end{array}$ & Stress regime \\
\hline 1 & $06^{\circ} / 012^{\circ}$ & $84^{\circ} / 169^{\circ}$ & $03^{\circ} / 282^{\circ}$ & $012^{\circ}$ & $102^{\circ}$ & 0.75 & Dextral strike-slip \\
\hline 2 & $11^{\circ} / 217^{\circ}$ & $01^{\circ} / 307^{\circ}$ & $79^{\circ} / 040^{\circ}$ & $040^{\circ}$ & $130^{\circ}$ & 0.50 & Thrust \\
\hline 3 & $00^{\circ} / 232^{\circ}$ & $00^{\circ} / 142^{\circ}$ & $89^{\circ} / 332^{\circ}$ & $059^{\circ}$ & $149^{\circ}$ & 0.50 & Thrust \\
\hline 4 & $16^{\circ} / 341^{\circ}$ & $73^{\circ} / 187^{\circ}$ & $07^{\circ} / 073^{\circ}$ & $163^{\circ}$ & $073^{\circ}$ & 0.75 & Dextral strike-slip \\
\hline Average orientation & $02^{\circ} / 005^{\circ}$ & $32^{\circ} / 274^{\circ}$ & $58^{\circ} / 099^{\circ}$ & - & - & 0.38 & - \\
\hline
\end{tabular}


The average stress orientations obtained from the fault plane solutions of the 4 major earthquakes show that the present-day direction of $(\sigma 1)$ in the Zakho - Silopi region is a nearly N-S trend $\left(\mathrm{N} 05^{\circ} \mathrm{E}\right)$ with slightly horizontal (plunge = $2^{\circ}$ ), while the minimum compressive stress $(\sigma 3)$ is a nearly $\mathrm{E}-\mathrm{W}$ orientation $\left(\mathrm{S} 81^{\circ} \mathrm{E}\right)$ and plunges at $\left(58^{\circ}\right)$ (Fig. 6 and Table 2). These results are consistent with the tectonic setting of this region. However, the accuracy of the calculated stress orientations at any region is strongly depends on the appropriate choice of the available focal mechanisms (Medina and El Alami, 2006).

\section{Lineament patterns}

The visual interpreted map of lineaments from $0.6 \mathrm{~m}$ resolution QuickBird images of the Zakho Silopi region was presented in Figure 7. Altogether 465 lineaments were mapped and characterized on QuickBird images based on the linear morphotectonic features, such as fracture zone traces, fault escarpments, linear ridges and valleys, linear cliff faces, linear rivers and drainage networks, as well as linear traces of vegetative covers. Lineaments range in length from $1.8 \mathrm{~km}$ to $17.2 \mathrm{~km}$. The lineament density map shows that the distribution of lineaments is not homogeneous within the study area because the majority of lineaments occur within the competent beds of the Eocene, Miocene and Pliocene sequences (Figs. 2, 7 and 8).

The analysis of lineament orientations in the Zakho - Silopi region reveals three distinct sets; N05 ${ }^{\circ}$, NE-SW, and NW-SE (Fig. 9). These three dominant sets are consistent with previous lineament studies, such as Numan and Bakose (1997), Alridha et al. (2012), Thannoun (2013). Fractures are the most common result of brittle deformation of rocks that formed by the tectonic stresses (Hancock, 1985; Pollard and Aydin, 1988; Mandl, 2005). The stress fields and fracture types at the time of fracturing can be determined from the geometry of fracture surfaces and bedding planes (Stearns, 1968; Hancock, 1985 and 1991; Dunne and Hancock, 1994) (Fig. 10). Following the neotectonic stress analysis of brittle tectonic structures presented by Hancock (1985 and 1991), the orientation of the three dominant lineament sets suggests that the present-day direction of $(\sigma 1)$ in the Zakho - Silopi region is $\mathrm{N}^{\circ} 5^{\circ} \mathrm{E}$ (Fig. 9). The same stress direction was also inverted from the earthquake focal mechanism solutions (Fig. 6 and Table 2).

\section{DISCUSSION}

The seismicity of the Zagros belt is resulted from the compressional reactivation of preexisting basement faults due to the active continental collision between Arabia and Eurasia (Berberian, 1981). The present-day rate of N-S continental convergence between Arabia and Eurasia is calculated from the GPS measurements to be at $18 \pm 2 \mathrm{~mm} /$ year (McClusky et al. 2000). The relative motion obtained from the GPS Euler vectors along the North Anatolian fault and the Zagros belt to the northeast are $(24 \pm 1 \mathrm{~mm} /$ year $)$ and $(19-23 \pm 1 \mathrm{~mm} /$ year), respectively; whereas in the Gulf of Aqaba and on the Dead Sea fault, the relative motion increasing from 5.6 to 7.5 $\mathrm{mm} /$ year ( $\pm 1 \mathrm{~mm} / \mathrm{year}$ ) from south to north (McClusky et al. 2003). Several areas of the Kurdistan region are seismically active as evidenced by historical and recent earthquakes, as well as most of the major earthquakes were sourced by the reactivation of thrust and strike-slip basement faults (Alsinawi and Issa, 1986; Fahmi et al., 1986; Ambraseys et al. 1994; Mohammad 1998; Alridha et al., 2012; Doski and Mohammad, 2016).

The location and trend of the subsurface basement faults may be detected by a linear distribution of earthquake epicentres; these patterns are called seismic lineaments (Nowroozi, 1995). The alignment of earthquake epicentres clearly indicates that there is a subsurface seismically active basement fault and could be the source of strong earthquakes in the future (Jacobi, 2002; Almeida-Filho et al., 2009; Talukdar and Barman, 2012; Saravanavel and Ramasamy, 2014; Phelps et al., 2015). Some of the seismic lineaments were interpreted along the southeastern region of the United States based on epicentral alignments of earthquakes (Nowroozi, 1995). The locations of these lineaments were interpreted as the intersection of pre-existing, weak planar zones with the earth's surface. Vlastos et al. (2002) identified active seismic lineaments in the Aegean area based on the linear clusters of strong earthquakes, and concluded that there is a good agreement between the seismically active linear structures and the seismotectonic setting of the Aegean area. 


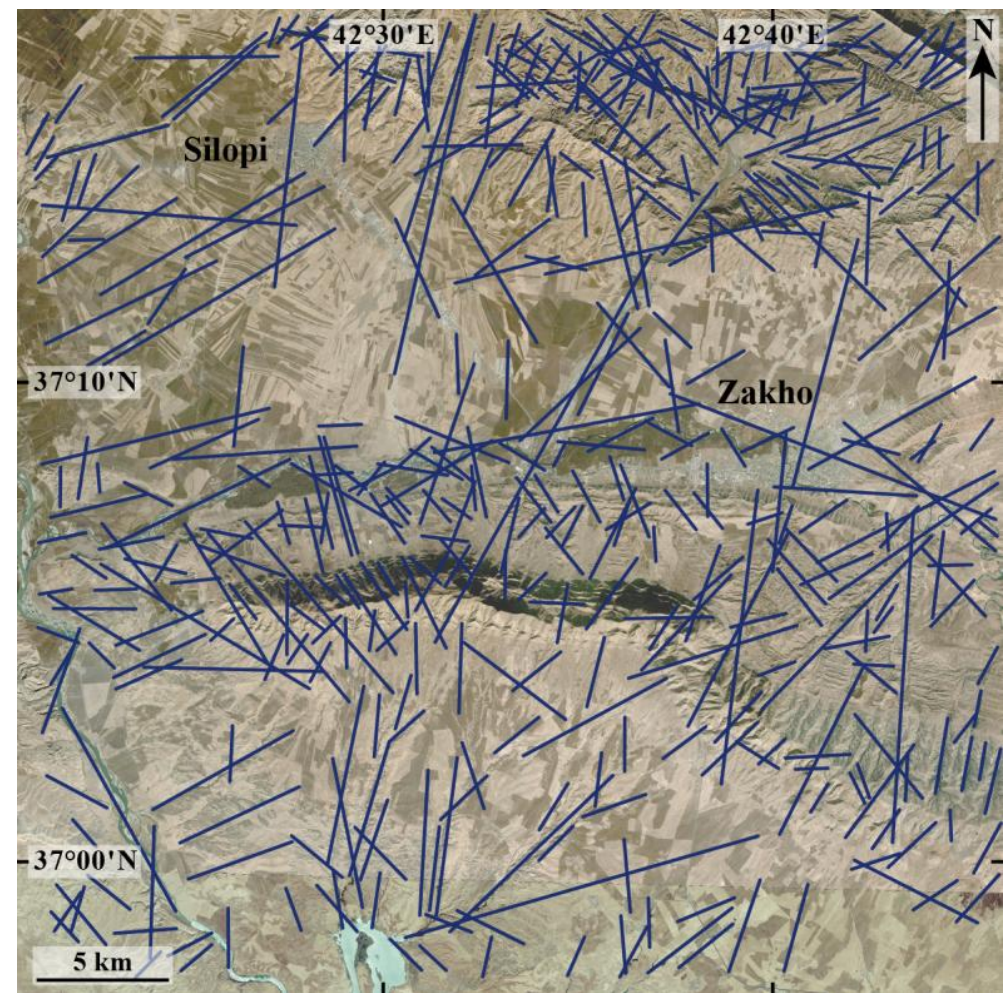

Fig.(7): Map showing the probable locations of lineaments that delineated by visual interpretation from $0.6 \mathrm{~m}$ resolution QuickBird images of the Zakho - Silopi region.

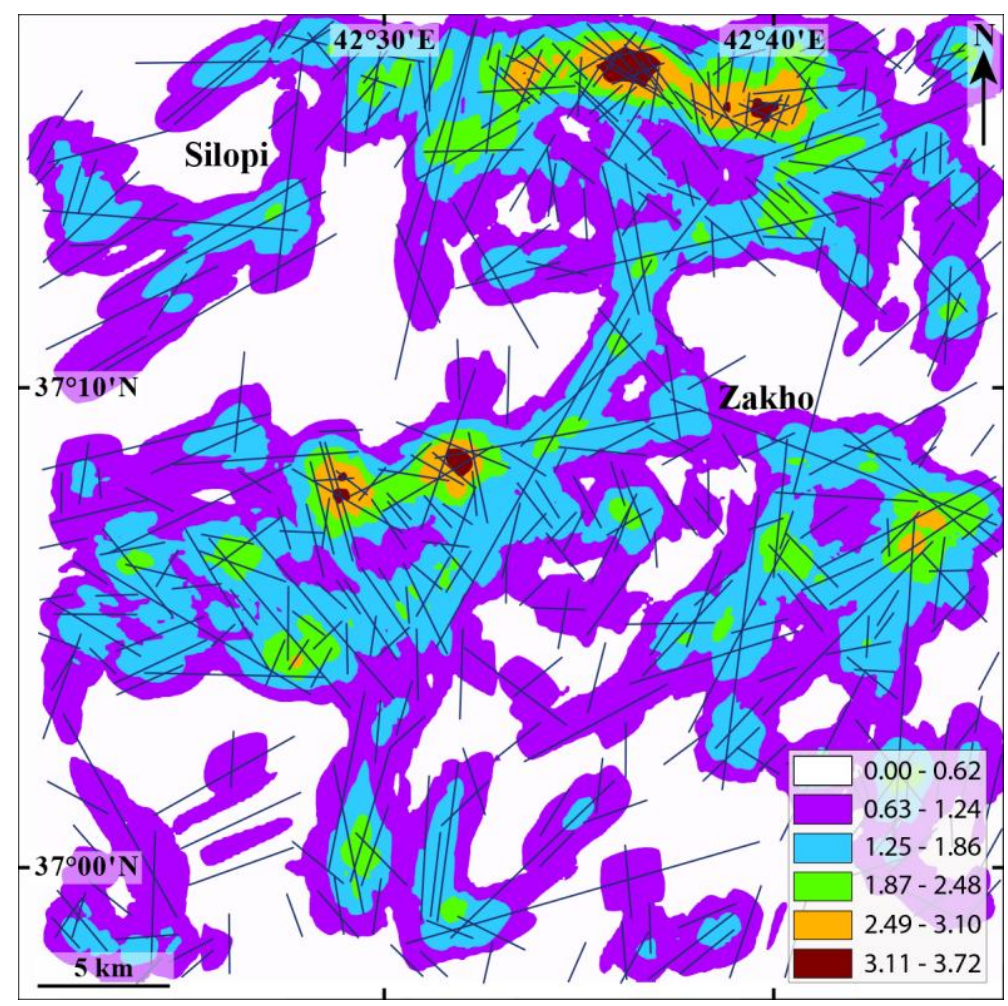

Fig.(8): Density map created from the total number of lineaments per square km area in the Zakho - Silopi region. 


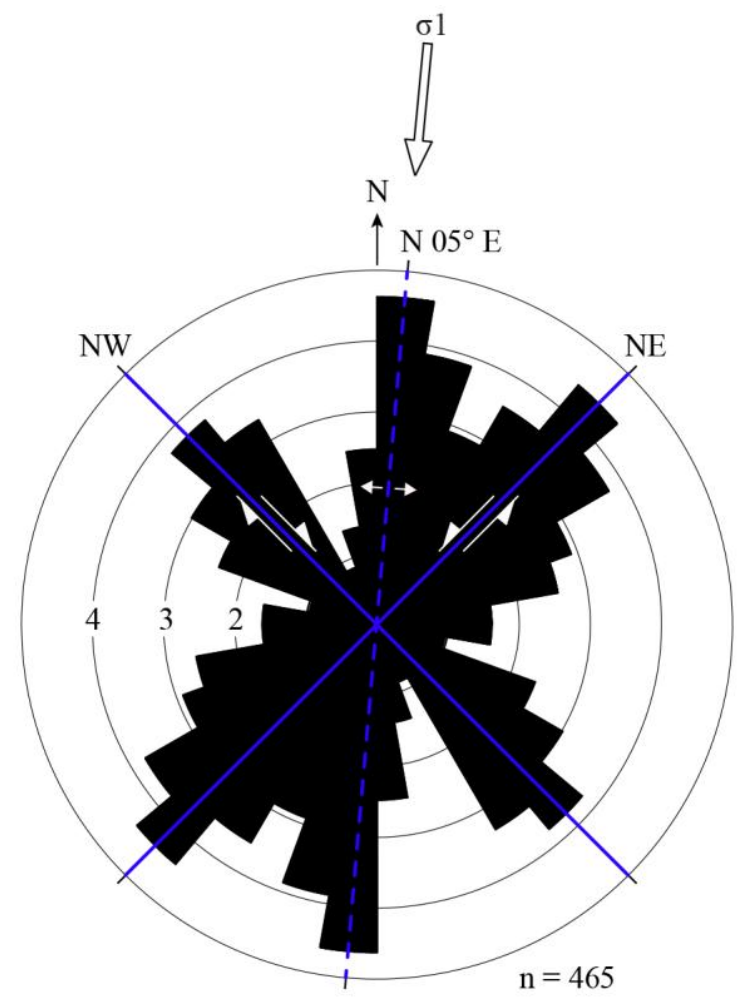

Fig. (9): Frequency rose diagrams showing the main orientation classes of lineaments within the Zakho - Silopi region.

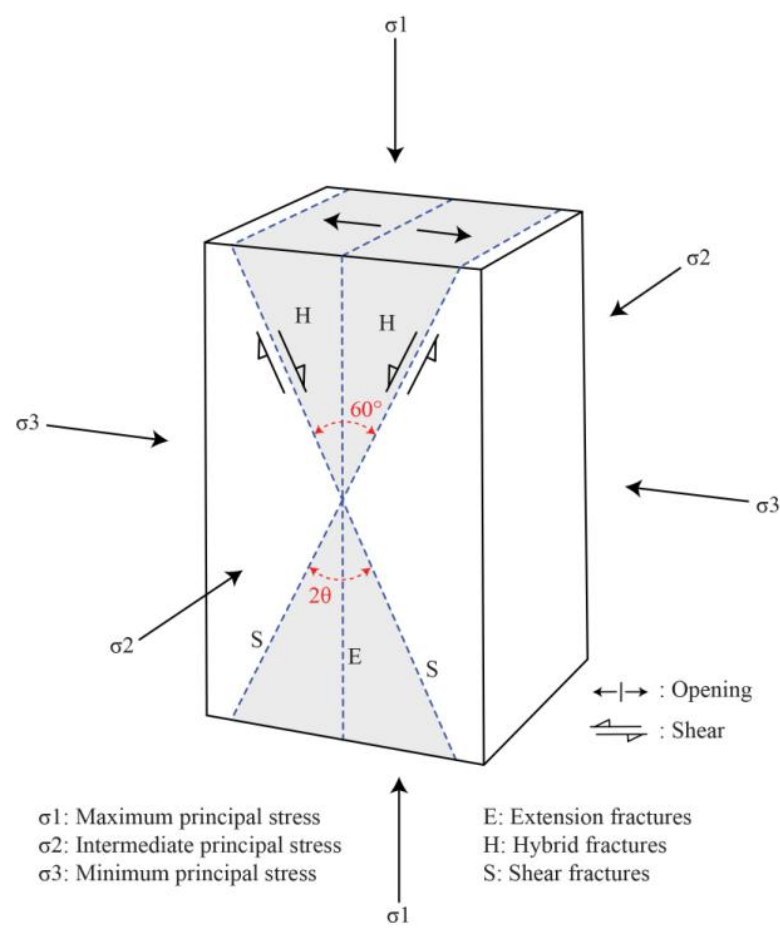

Fig. (10): Relationships between fracture types and principal stress axes during the compressive failure of brittle materials (from Hancock, 1985 and 1991). 
Four potentially active NE- and NW-trending seismic lineaments were inferred in the Zakho Silopi region based on the linear distribution of earthquake epicentres with magnitudes greater than (3.0) (Fig. 11). These linear structures extend from $22 \mathrm{~km}$ to $42 \mathrm{~km}$. There is a good agreement between the orientation of nodal fault planes and the trend of seismic lineaments, except in the case of focal mechanism (no. 3) and seismic lineament (no. B) (Figs. 5 and 11). This suggests a fifth seismic lineament with $\mathrm{NW}$-trending, passes through the epicentral location of earthquake focal mechanism (no. 3) and intersects with the seismic lineament (no. B). The fifth seismic lineament is considered as "uncertain" due to a few number of its earthquake epicentres. The seismic lineaments in the Zakho - Silopi region may represent reactivated basement faults that cause major earthquakes over this region (Fig. 11). Therefore, the area along or around these active seismic lineaments has the potential to produce major earthquakes in the future.

It is inferred from the trend analysis of lineament patterns and seismic lineaments that the basement faults in the Zakho - Silopi region are characterized by three linear tectonic trends: roughly N-S, NE-SW and NW-SE (Figs. 9 and 11). Many of the basement faults were exposed at the surface as lineaments or faults (Plafker, 1964; Henden, 1981; Numan and Al-Azzawi, 1993; Singh and Singh, 2005; Wilson et al., 2010; Saravanavel and Ramasamy, 2014; Sissakian et al., 2014; Abdunaser, 2015). The Zagros basement in Iran consists of seismically "active" and "inactive" faults with dominant N-S, NE-SW and NW-SE trends (Bahroudi, 2003). The same basement fault trends were also recognized by Burberry (2015) within the Kirkuk Embayment (Kurdistan) using the gravity data, fault maps of Jassim and Buday (2006a) and lineament analyses: the NW-SE 'Najd system' trend, N-S 'Nabitah system' trend, and the NE-SW 'Transverse system' trend. Kent (2010) identified three tectonic inversion trends in northern Iraq and Syria: the NW Erythrean 'Zagros' trend, the E-W Tethyan 'Taurus' trend, and the NE Aualitic 'Palmyra' trend, as well as concluded that these regional trends are related to the basement fault systems that probably originated in Paleozoic as normal faults, and inverted into thrust faults.

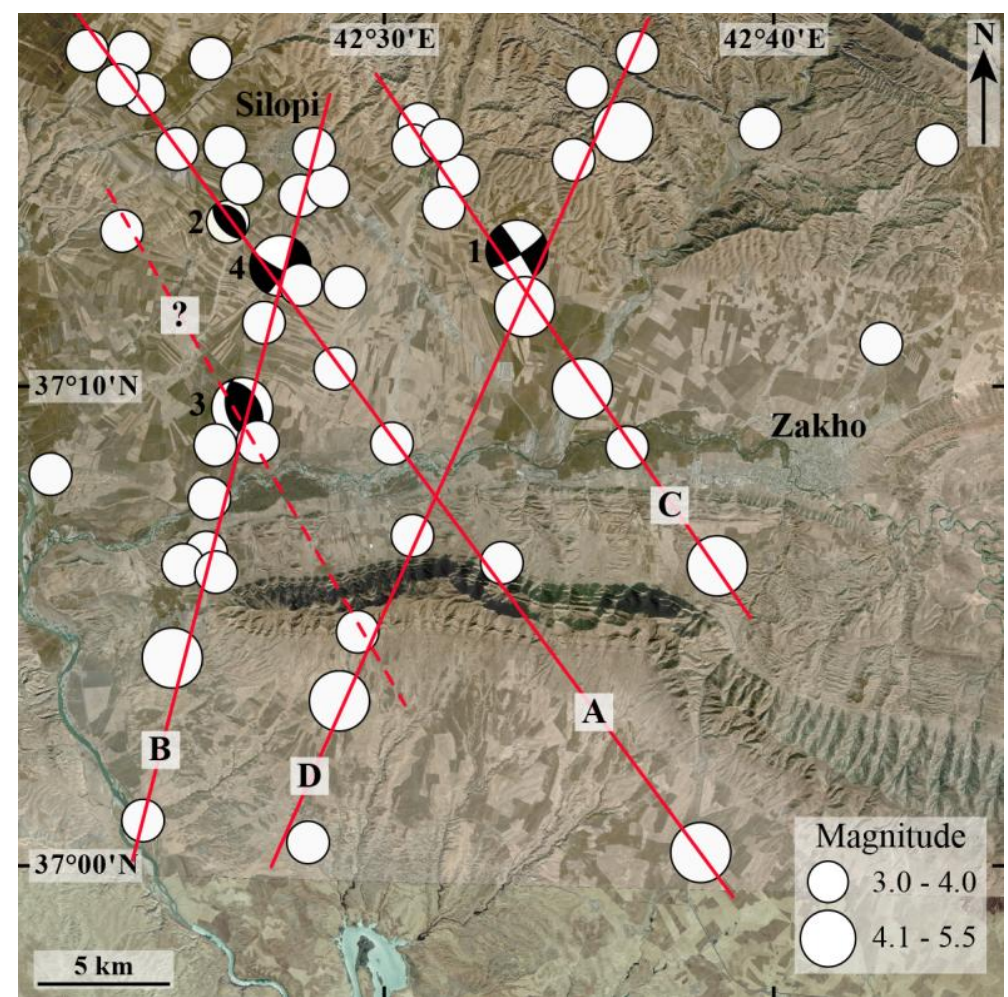

Fig. (11): Potential seismic lineaments within the Zakho - Silopi region. 
Ali et al. (2013) studied the basement structure in the United Arab Emirates using the gravity anomaly data, and concluded that the basement of the Arabian plate is characterized by N-, NE- and $\mathrm{NW}$-trending lineaments. Four major fault trends were also recognized in the Arabian basement: $\mathrm{N}$ $\mathrm{S}$ "Arabian trend", NE-SW "Aualitic trend", NWSE "Erythraean trend" and E-W "Tethyan trend" (von Wissmann et al., 1943; Henson, 1951; Edgell, 1992). The N-S "Arabian trend" lineaments associated with the extensional basement structures (horsts and grabens) that were periodically reactivated throughout the time, whereas the NE- and NW-trending lineaments are represented by the left-lateral and right-lateral strike-slip basement faults, respectively (Henson, 1951; Edgell, 1992).

The basement faults in the Zakho - Silopi region were probably formed in Late Precambrian as normal faults, and subsequently inverted into thrust faults as well as reactivated continuously from the Late Cretaceous to the continental collision between Arabia and Eurasia from the Late Eocene onwards (Numan, 1997; Jassim and Goff 2006; Kent, 2010).

\section{CONCLUSION}

1- The present-day direction of $(\sigma 1)$ in the Zakho - Silopi region as inferred from the inversion of fault plane solutions and lineament analysis is $\mathrm{N} 05^{\circ} \mathrm{E}$. This direction is entirely consistent with the active N-S shortening across the Kurdistan region due to the Mid-Miocene collision of Arabia with the Turkish and Iranian plates.

2- The seismic activity in the Zakho - Silopi region is mainly related to the neotectonic reactivation of pre-existing thrust and strike-slip basement faults by a nearly N-S compression that resulted from the on-going convergence of Arabia and Eurasia./////3- Four active seismic lineaments were detected in the Zakho - Silopi region by the linear distribution of earthquake epicentres. These reactivated basement faults have the potential to produce large earthquakes in the future. Therefore, a more detailed earthquake risk assessment is necessary.

4- Three distinct basement fault trends were identified from the orientation analysis of lineament patterns and seismic lineaments in the Zakho - Silopi region; nearly N-S, NE-SW and NW-SE. These basement faults were periodically reactivated from Late Cretaceous onwards.

\section{REFERENCES}

- Abdulnaby, W., Mahdi, H., Al-Shukri, H., and Numan, N.M.S. (2014a). Stress patterns in northern Iraq and surrounding regions from formal stress inversion of earthquake focal mechanism solutions. Pure and Applied Geophysics 171 (9), 2137-2153.

- Abdulnaby, W., Mahdi, H., Numan, N.M.S., and AlShukri, H. (2014b). Seismotectonics of the Bitlis-Zagros fold and thrust belt in northern Iraq and surrounding regions from moment tensor analysis. Pure and Applied Geophysics 171 (7), 1237-1250.

- Abdunaser, K.M. (2015). Satellite Imagery for Structural Geological Interpretation in Western Sirt Basin, Libya: Implication for Petroleum Exploration. Geosciences 5 (1), 8-25.

- Alavi, M. (1994). Tectonics of the Zagros orogenic belt of Iran: New data and interpretations. Tectonophysics 229, 211-238.

- Alavi, M. (2004). Regional stratigraphy of the Zagros fold-thrust belt of Iran and its proforeland evolution. American Journal of Science 304, 120.

- Alavi, M. (2007). Structures of the Zagros fold-thrust belt in Iran. American Journal of Science 307, 1064-1095.

- Al-Daghastani, H.S., and Daood, M.T. (2005). Correlation between seismic activity and tectonic elements in Nineveh governorate. Iraqi Journal of Earth science 5 (2), 1-8.

- Ali, M.Y., Watts, A.B., and Farid, A. (2013). Gravity anomalies of the United Arab Emirates: Implications for basement structures and infraCambrian salt distribution. GeoArabia 18 (4), 49-80.

- Allen, M., Jackson, J., and Walker, R. (2004). Late Cenozoic reorganization of the Arabia-Eurasia collision and the comparison of short-term and long-term deformation rates. Tectonics 23, TC2008, doi:10.1029/2003TC001530.

- Allen, M.B., Saville, C., Blanc, E.J-P., et al. (2013). Orogenic plateau growth: Expansion of the Turkish-Iranian Plateau across the Zagros foldand-thrust belt. Tectonics 32 (2), 171-190.

- Almeida-Filho, R., Rossetti, D.F., Miranda, F.P., et al. (2009). Quaternary reactivation of a basement structure in the Barreirinhas Basin, Brazilian. Quaternary Research 72 (1), 103-110.

- Alridha, N.A., Baqir, R.A., and Hamid, A.R. (2012). Seismicity and seismotectonic study for Altunkopri dam site north Iraq. Iraqi Journal of Science 53 (3), 595-601. 
- Alsinawi, S.A. (2002). Seismicity, seismotectonics, crustal structure and attenuation data on Iraq. RELEMR Meetings, Antakya, Turkey.

- Alsinawi, S.A., and Issa, A.A. (1986). Seismicity and seismotectonics of Iraq. Journal of the Geological Society of Iraq 19 (2), 39-59.

- Ambraseys, N.N., Melville, C.P., and Adams, R.D. (1994). The seismicity of Egypt, Arabia, and the Red Sea: a historical review. Cambridge University, London.

- Authemayou, C., Bellier, O., Chardon, D., et al. (2009). Quaternary slip-rates of the Kazerun and the Main Recent Faults: active strike-slip partitioning in the Zagros fold-and-thrust belt. Geophysical Journal International 178 (1), 524540.

- Bahroudi, A. (2003). The effect of mechanical characteristics of basal decollement and basement structures on deformation of the Zagros basin. PhD Thesis, Uppsala University, $43 \mathrm{p}$.

- Berberian, M. (1981). Active faulting and tectonics of Iran. In: Gupta, H.K., Delany, F.M. (eds), Zagros Hindu Kush Himalaya Geodynamic Evolution. American Geophysical Union, Washington, Geodynamics Series 3, 33 - 69.

- Bernardi, F., Lauciani, V., Lomax, A., et al. (2014). Performance analysis of the Early-Est software within the tsunami early warning system installed at the INGV. EGU General Assembly, held 27 April - 2 May, 2014 in Vienna, Austria.

- Bondár, I., Myers, S.C., Engdahl, E.R., and Bergman, E.A. (2004). Epicentre accuracy based on seismic network criteria. Geophysical Journal International 156 (3), 483-496.

- Burberry, C.M. (2015). The effect of basement fault reactivation on the Triassic-recent geology of Kurdistan, North Iraq. Journal of Petroleum Geology 38, 37-58.

- Dawson, J., and Tregoning, P. (2007). Uncertainty analysis of earthquake source parameters determined from InSAR: A simulation study. Journal of Geophysical Research 112 (B9), B09406, doi:10.1029/2007JB005209.

- Delvaux, D., and Sperner, B. (2003). Stress tensor inversion from fault kinematic indicators and focal mechanism data: the TENSOR program. In: Nieuwland D, editor. New Insights into Structural Interpretation and Modelling. Geological Society, London, Special Publications 212, 75-100.

- Doski, J.A.H., and McClay, K.R. (2011). Potential hydrocarbon traps in the detachment folds of the Duhok region, Kurdistan, northern Iraq. AAPG Search and Discovery Article \#90124, AAPG
Annual Convention and Exhibition, April 10-13, 2011, Houston, Texas.

- Doski, J.A.H., and Mohammad, R.J. (2016). Tectonic analysis of the Shaikhan earthquakes, Kurdistan, northern Iraq. Arabian Journal of Geosciences 9 (1), Article 16.

- Dunne, W.M., and Hancock, P.L. (1994). Palaeostress analysis of small-scale brittle structures. In: Hancock, P.L. (ed), Continental Deformation, Pergamon Press, Great Britain, 101-120.

- Edgell, H.S. (1992). Basement tectonics of Saudi Arabia as related to oil field structures. Proceedings of the International Conferences on Basement Tectonics 3, 169-193.

- Fahmi, K.J., Al Salim, M.A.H., and Ayar, B.S. (1986). Recent earthquake activity in the Lesser Zab region of northeastern Iraq. Tectonophysics 131, 89-111.

- Gomez-Capera, A.A., Rovida, A., Gasperini, P., et al. (2015). The determination of earthquake location and magnitude from macroseismic data in Europe. Bulletin of Earthquake Engineering 13 (5), 1249-1280.

- Hancock, P.L. (1985). Brittle microtectonics: principles and practice. Journal of Structural Geology 7, 437-457.

- Hancock, P.L. (1991). Determining contemporary stress directions from neotectonic joint systems. Philosophical Transactions: Physical Sciences and Engineering 337 (1645), 29 - 40.

- Henden, I. (1981). Lineaments map of Turkey from Landsat imagery and selecting target areas for mineral exploration, relationship of regional lineaments to earthquake epicenters, mineral waters and hot spring. Bulletin of the Mineral Research and Exploration 96, 25-33.

- Henson, F.R.S. (1951). Observations on the geology and petroleum occurrences of the Middle East. 3rd World Petroleum Congress, The Hague, Proceedings 1, 118-140.

- Hessami, K. (2002). Tectonic history and present-day deformation in the Zagros fold-thrust belt. Acta Universitatis Upsaliensis, Comprehensive Summaries of Uppsala Dissertations from the Faculty of Science and Technology 700, 13 p.

- Holland, M. (2012). Evaluation of factors influencing transmissivity in fractured hard-rock aquifers of the Limpopo Province. Water SA, International Conference on Groundwater Special Edition 38 (3), $379-390$.

- Husen, S., and Hardebeck, J.L. (2010). Earthquake location accuracy. Community Online Resource for Statistical Seismicity Analysis, doi:10.5078/corssa-55815573. 
- Jackson, J.A., Fitch, T.J., and McKenzie, D.P. (1981). Active thrusting and the evolution of the Zagros fold belt. Geological Society, London,Mohammad, R.J. (1998). The Earthquake of Dohuk 1997. Special Publications 9, 371-379.

- Jacobi, R.D. (2002). Basement faults and seismicityMostafazadeh, M., Alptekin, O., and Oncel, A.O. (2000). in the Appalachian basin of New York State. Tectonophysics 353, 75-113.

- Jasim, N.A. (2013). Seismicity evaluation of central and southern Iraq. MSc thesis, University of Baghdad, $126 \mathrm{p}$.

- Jassim, S.Z. (2006). Late Precambrian development of the Arabian Plate. In: Jassim, S.Z., Goff, J.C. (eds), Geology of Iraq. Dolin, Prague and Moravian Museum, Czech Republic, 25-31.

- Jassim, S.Z., and Buday, T. (2006a). Tectonic Framework. In: Jassim, S.Z., Goff, J.C. (eds), Geology of Iraq. Dolin, Prague and Moravian Museum, Czech Republic, 45-56.

- Jassim, S.Z., and Buday, T. (2006b). Units of the Unstable Shelf and the Zagros Suture. In: Jassim, S.Z., Goff, J.C. (eds), Geology of Iraq. Dolin, Prague and Moravian Museum, Czech Republic, 71-83.

- Jassim, S.Z., and Buday, T. (2006c). Late Turonian Danian Megasequence AP9. In: Jassim, S.Z., Goff, J.C. (eds), Geology of Iraq. Dolin, Prague and Moravian Museum, Czech Republic, 141-154.

- Jassim, S.Z., and Goff, J.C. (2006). Geology of Iraq. Dolin, Prague and Moravian Museum, Czech Republic, $341 \mathrm{p}$.

- Kent, W.N. (2010). Structures of the Kirkuk embayment, northern lraq: Foreland structures or Zagros fold belt structures?. GeoArabia 15 (4), 147-188.

- Ketin, I. (1966). Tectonic Units of Anatolia (Asia Minor). Bulletin of the Mineral Research Exploration, Institute of Turkey, Foreign Edition 66, 23-34.

- La Pointe, P.R., Cladouhos, T., and Follin, S. (1999). Calculation of displacements on fractures intersecting canisters induced by earthquakes: Aberg, Beberg and Ceberg examples. Svensk Kärnbränslehantering $A B$, SKB TR-99-03, 103 p.

- Lattman, L.H. (1958). Technique of mapping geologic fracture traces and lineaments on aerial photographs: Photogrammetric Engineering 24 (4), 568-576.

- Mandl, G. (2005). Rock joints, the mechanical genesis. Springer-Verlag, Berlin, $221 \mathrm{p}$.

- McClusky, S., Balassanian, S., Barka, A., et al. (2000). Global positioning system constraints on plate kinematics and dynamics in the eastern Mediterranean and Caucasus. Journal of Geophysical Research 105 (B3), 5695-5719.

- McClusky, S., Reilinger, R., Mahmoud, S., et al. (2003). GPS constraints on Africa (Nubia) and Arabia plate motions. Geophysical Journal International 155 (1), $126-138$.

- Medina, F., and El Alami, S.O. (2006). Focal Mechanisms and state of stress in the Al Hoceima area (Central Rif,
Morocco). Bulletin de l'Institut Scientifique, Rabat, section Sciences de la Terre 28, 19-30.

Journal of Dohuk University 1 (2), 23-29.

Body waveform modeling of five moderately earthquakes in the Zagros fold thrust belt. Journal of Seismology and Earthquake Engineering 2 (3), 1 - 10.

- Nowroozi, A.A. (1995). On association of seismic lineaments and stress patterns of the southeastern United States: Criteria of failure. International Conferences on Recent Advances in Geotechnical Earthquake Engineering and Soil Dynamics, Volume II, Paper No. 9.02, 619 -625 .

- Numan, N.M.S. (1997). A plate tectonic scenario for the Phanerozoic succession in Iraq. Iraqi Geological Journal 30 (2), 85 - 110.

- Numan, N.M.S. (2000). Major Cretaceous tectonic events in Iraq. Rafidain Journal of science 11 (3), $32-52$.

- Numan, N.M.S. (2001). Cretaceous and Tertiary Alpine subductional history in northern Iraq. Iraqi Journal of Earth Science 1 (2), 59 - 74.

- Numan, N.M.S., and Al-Azzawi, N.K.B. (1993). Structural and geotectonic interpretation of vergence directions of anticlines in the foreland folds of Iraq. Abhath Al-Yarmouk, Yarmouk University, Pure Science and Engineering Series 2, 57-73.

- Numan, N.M.S., and Bakose, G.Y.B. (1997). Lineaments: questions on the veracity of their relationships in the western and southern deserts of Iraq. ITC Journal 1 (1), 41 - 48.

- Okay, A.I. (2008). Geology of Turkey: A synopsis. Anschnitt 21, 19-42.

- Oros, E. (2013). Analysis of two earthquake sequences occurred in 2012 in the Timisoara area, Romania. Romanian Journal of Physics 58, 970-986.

- Phelps, G.A., Schmidt, K.M., and Barall, M. (2015). Comparison of 1989 Loma Prieta earthquake damage to mapped lineaments along the range front of the Santa Cruz Mountains, California. Geosphere 11 (2), 342-353.

- Plafker, G. (1964). Oriented Lakes and Lineaments of Northeastern Bolivia. GSA Bulletin75 (6), 503-522.

- Pollard, D.D., and Aydin, A. (1988). Progress in understanding jointing over the past century. Geological Society of America Bulletin 100, 1181-1204.

- Presti, D., Billi, A., Orecchio, B., et al. (2013). Earthquake focal mechanisms, seismogenic 
stress, and seismotectonics of the Calabrian Arc, Italy. Tectonophysics 602, 153-175.

- Sander, P. (2007). Lineaments in groundwater exploration: a review of applications and limitations. Hydrogeology Journal 15 (1), 71-74.

- Saravanavel, J., and Ramasamy, S.M. (2014). GIS based 3D visualization of subsurface and surface lineaments / faults and their geological significance, northern Tamil Nadu, India. International Archives of the Photogrammetry, Remote Sensing and Spatial Information Sciences XL-8 (1), 469-476.

- Sasaki, S., and Kaieda, H. (2002). Determination of Stress State from Focal Mechanisms of Microseismic Events Induced During Hydraulic Injection at the Hijiori Hot Dry Rock Site. Pure and Applied Geophysics 159 (1), 489-516.

- Seber, D., Steer, D., Sandvol, E., et al. (2000). Design and development of information systems for the geosciences: An application to the Middle East. GeoArabia 5 (2), 295 - 322.

- Sharland, P.R., Archer, R., Casey, D.M., et al. (2001). Arabian Plate Sequence Stratigraphy. GeoArabia Special Publication 2, Gulf Petrolink, Bahrain, $371 \mathrm{p}$.

- Singh, V.P., and Singh, R.P. (2005). Changes in stress pattern around epicentral region of Bhuj earthquake of 26 January 2001. Geophysical Research Letters 32 (24), L24309, doi:10.1029/2005GL023912.

- Singhal, B.B.S., and Gupta, R.P. (2010). Applied hydrogeology of fractured rocks, Second Edition, Springer Science+Business Media B.V., 420 p.

- Sissakian, V.K., Al-Ansari, N., and Knutsson, S. (2014). Origin of some transversal linear features of NE-SW trend in Iraq, and their geological characters. Natural Science 6, 996 1011.

- Snoke, J.A. (2003). FOCMEC: FOcal MEChanism determinations. In: Lee WHK, Kanamori $\mathrm{H}$, Jennings $\mathrm{P}$, Kisslinger $\mathrm{C}$, editors. International Handbook of Earthquake and Engineering Seismology 85.12, Academic Press.

- Snoke, J.A., Munsey, J.W., Teague, A.G., and Bollinger, G.A. (1984). A program for focal mechanism determination by combined use of polarity and SV-P amplitude ratio data. Earthquake notes 55, 15.

- Stearns, D.W. (1968). Certain aspects of fracture in naturally deformed rocks. In R.E. Rieker, ed., NSF advanced science seminar in rock mechanics, Bedford, Cambridge Research Laboratories, 97-118.
- Stefouli, M., Angellopoulos, A., Perantonis, S., et al. (1996). Integrated analysis and use of remotely sensed data for the seismic risk assessment of the southwest Peloponessus Greece. First congress of the Balkan Geophysical Society, Athens, Greece, 23-27.

- Talebian, M., Jackson, J., 2002. Offset on the Main Recent Fault of NW Iran and implications for the late Cenozoic tectonics of the ArabiaEurasia collision zone. Geophysical Journal International 150 (2), 422-439.

- Talukdar, P., and Barman, N.C. (2012). Seismic Activity and Seismotectonic Correlation with Reference to Northeast India. IOSR Journal of Applied Physics 2 (2), 24-29.

- Thannoun, R.G. (2013). Automatic extraction and geospatial analysis of lineaments and their tectonic significance in some areas of northern Iraq using remote sensing techniques and GIS. International Journal of Enhanced Research in Science Technology \& Engineering 2 (2), 1-11.

- Vlastos, S., Papadimitriou, E., Papazachos, C., and and Karakostas, V. (2002). Determination of seismic lineaments in the Aegean area and deformation velocities. Eleventh General Assembly of the Wegener Project, Athens, Greece.

- von Wissmann, H., Rathjens, C., and Kossmat, F. (1943). Beiträge zur Tektonik Arabiens. Geologische Rundschau 33 (4), 221 - 353.

- Wilson, R.W., Holdsworth, R.E., Wild, L.E., et al. (2010). Basement-influenced rifting and basin development: a reappraisal of post-Caledonian faulting patterns from the North Coast Transfer Zone, Scotland. Geological Society, London, Special Publications 335, 795-826.

- Witthuhn-Rolf, K.M. (1997). A structural analysis of the Midcontinent Rift in Michigan and Minnesota. Geological Society of America Special Papers 312, 97-113.

- Yang, W., Hauksson, E., and Shearer, P.M. (2012). Computing a large refined catalog of focal mechanisms for southern California (19812010): Temporal stability of the style of faulting. Bulletin of the Seismological Society of America 102 (3), 1179-1194.

- Zoback, M.D. (2007). Reservoir geomechanics. Cambridge University Press, Cambridge and New York, 449 p. 


\section{دوباره ئهنتيف كرنا بِيّك هانيّن شهنكهستهيى ل دمقهر ا زاخو - سلوبى يا سنورى دناقبهرا كوردستانا عير اقنى و توركيا}

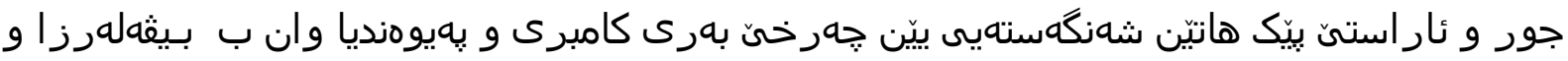

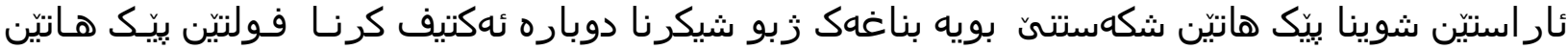

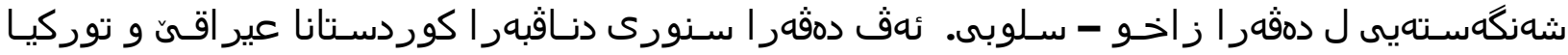

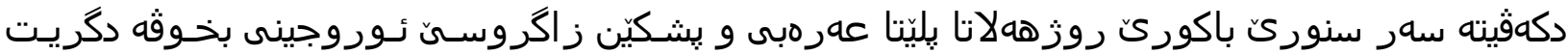

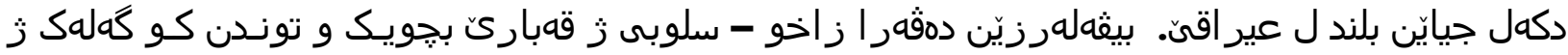

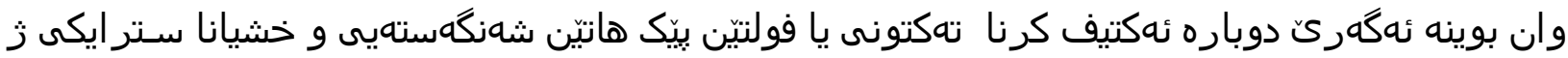

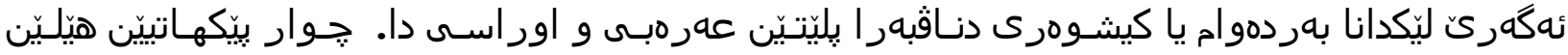

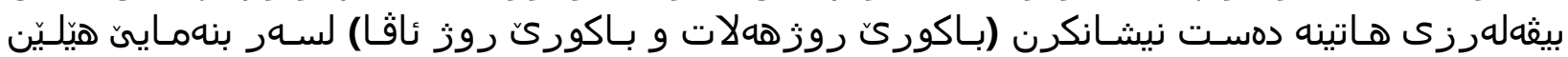

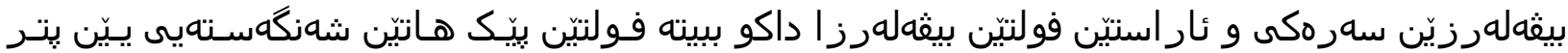

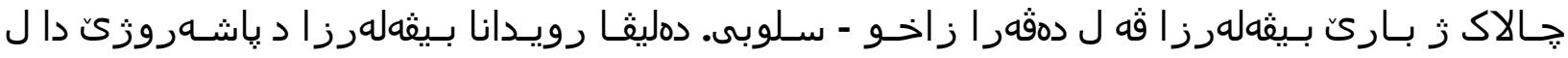

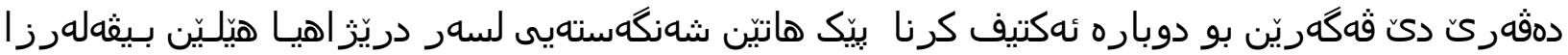

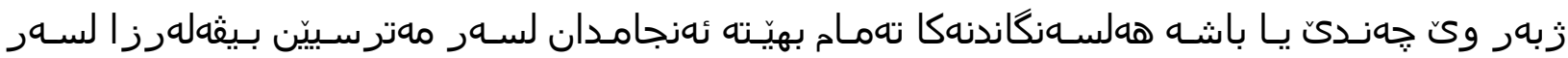

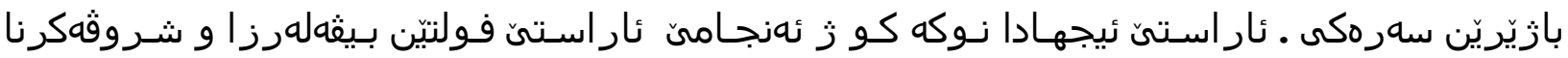

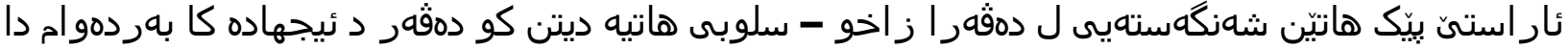

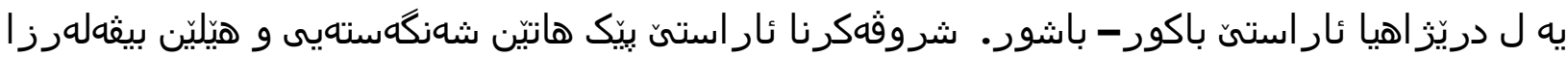

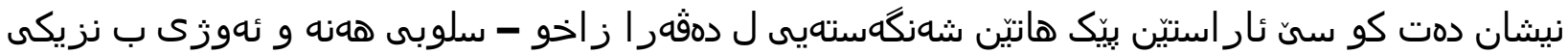

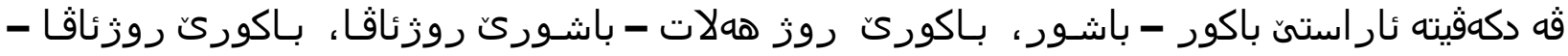

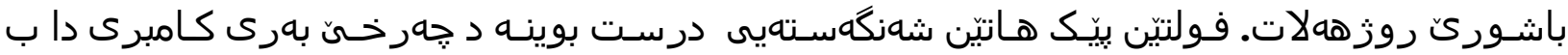

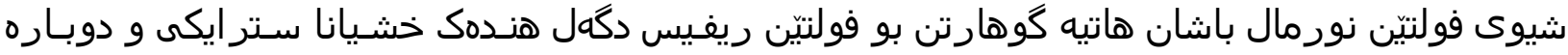

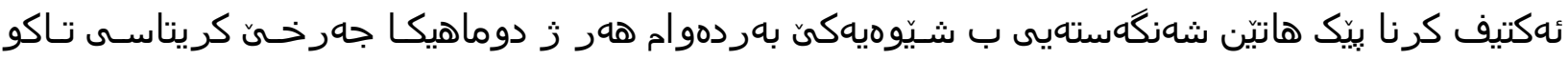

اعادة التتشيط للفوالق القاعدية في منطقة زاخو - سلوبي الحدودية بين كردستان العراق و توركيا 
أن طبيعة وأتجاه التراكيب القاعدية لعصر ما قبل الكامبري المتأخر وعلاقتها بالتوزيع الزلزالي الزيا

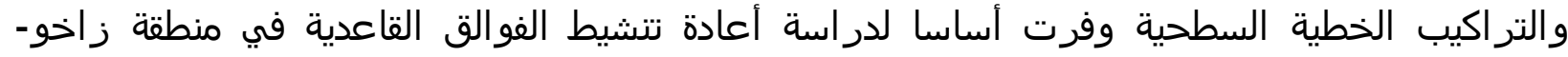

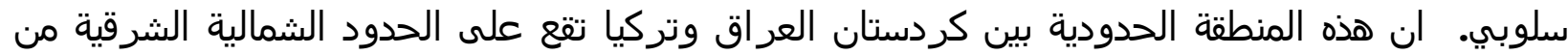

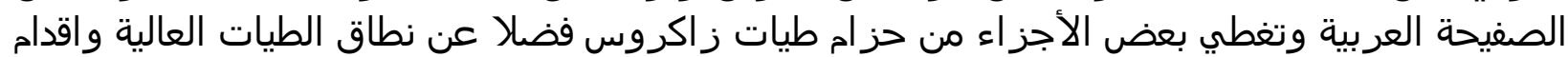

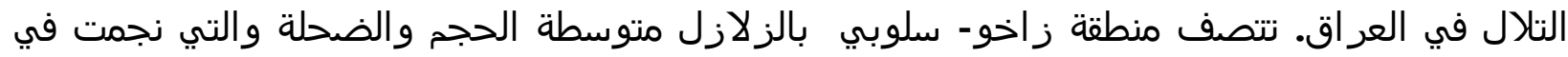

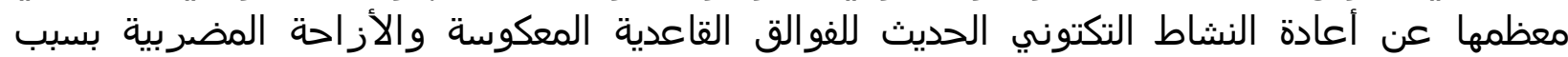

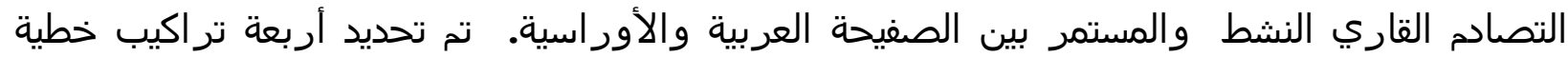

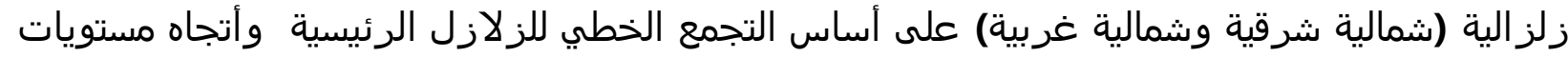

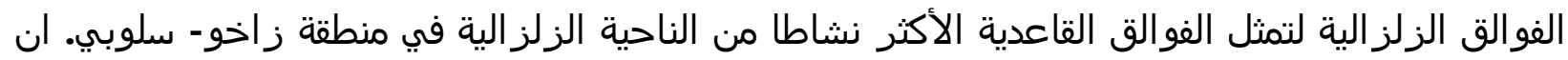

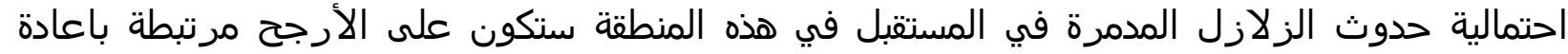

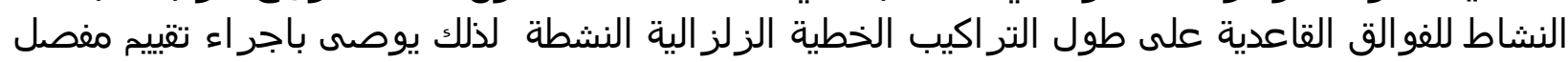

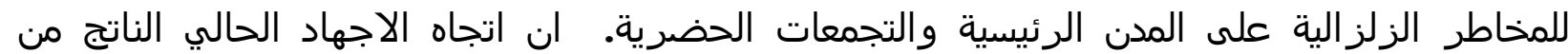

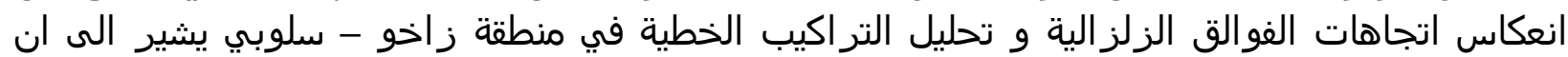

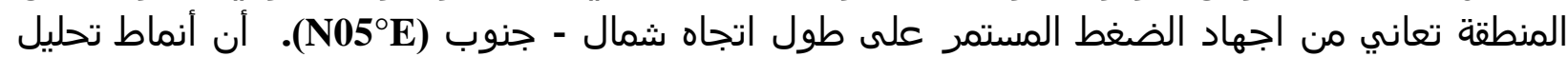

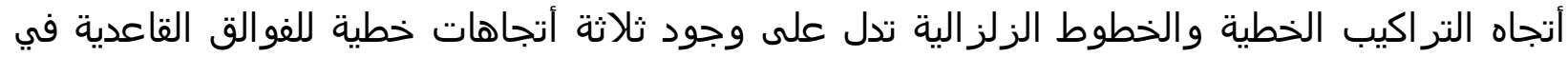

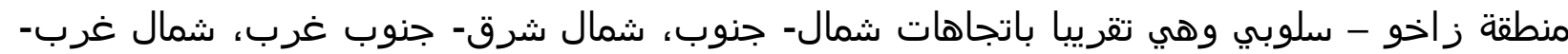

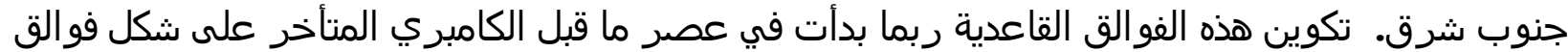

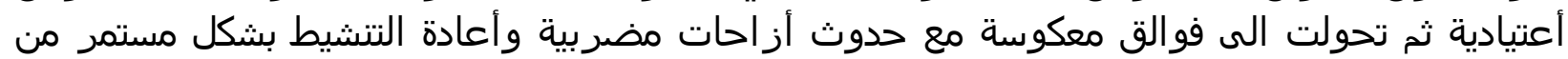
اواخر العصر الكريتاسي الى الوقت الحاضر. معاض مدورن 